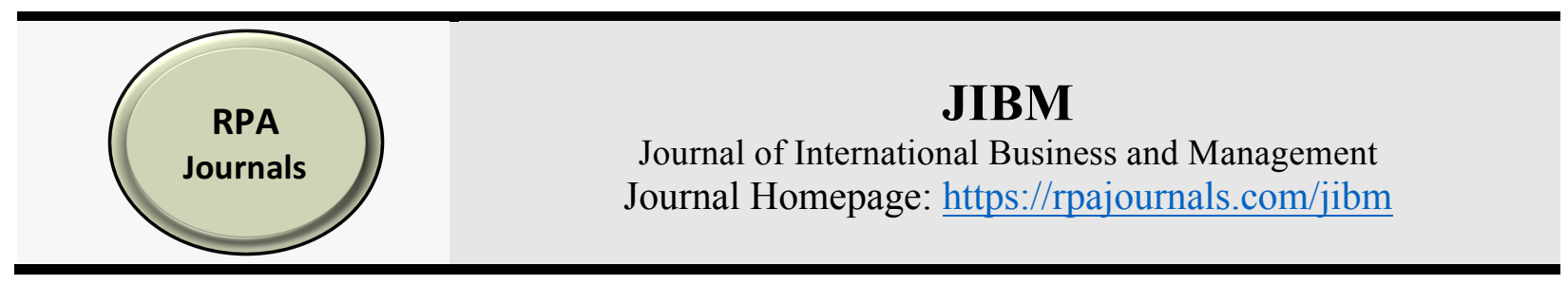

\title{
Relationship Between Idealized Leadership Behavior and Change Initiative Success
}

\author{
Norma N. Mgqibi ${ }^{1}$ * \\ Chad C. Sines ${ }^{2}$ \\ Walden University, United States ${ }^{1,2}$
}

\begin{abstract}
Change is an important process that organizations must go through to remain competitive. However, change initiatives fail resulting in costly financial losses for the organizations. Idealized behavior is critical to the effectiveness of change initiatives. The purpose of this quantitative correlational study was to examine the relationship between idealized behavior and change initiative success. Midlevel managers who successfully implemented 1 or more change initiatives in any industry in the United States $(\mathrm{n}=105)$ were conveniently selected to participate in the study. The Multifactor Leadership Questionnaire (MLQ) Form 5X-Short was used to measure idealized behavior and the Project Implementation Profile (PIP) was used to measure change initiative success. The overall model, simple linear regression, revealed a statistically significant relationship between idealized behavior and change initiative success, $F(1$, $103)=7.803, \mathrm{p}<0.006, \mathrm{R}^{2}=0.070$. The independent variable (change initiative success) was also significant, $\mathrm{p}<0.006$. The results of the study provide a practical model for understanding the relationship between idealized behavior and change initiative success.
\end{abstract}

Keywords: Idealized Behavior, Transformational Leadership, Change Initiative, Change Implementation, Correlational Study

*Corresponding author: Norma N. Mgqibi; Email: nomahlathi.mgqibi@waldenu.edu

DOI: https://rpajournals.com/jibm-2020-32

\section{Introduction}

Today, organizations encounter numerous challenges from disruptive technologies to unstable financial markets. The ability to adapt quickly in a dynamic environment is an important factor to success and survival. Thus, change initiative success is a critical factor to remain competitive in a highly dynamic environment (Al-Haddad \& Kotnour, 2015). An organization's success no longer depends on competitive advantage but on its ability to effectively manage change, especially in a market environment that is constantly changing. Too often, change initiatives often fail and business leaders are concerned about the high rates of failure (Heckmann, Steger, \& Dowling, 2016). Successful implementation of change initiatives is imperative for organizations to remain competitive.

According to Heckmann et al (2016), as high as $70 \%$ of change initiatives fail. One of the causes of failure is the inability of businesses to evolve with changing market, which results in loss of competitive advantage. Achieving change initiative success is challenging as evidenced by high implementation failure rates. Successful implementation of organizational change projects is critical 
for firms to succeed in a dynamic and competitive environment. Thus, understanding a relationship between idealized behavior and change initiative success is critical to success of change initiatives.

An unsuccessful change implementation can cause an organization to lose a competitive advantage. The organization's competitive advantage can fall behind competitors, especially competitors that have been successfully at implementing change projects. An unsuccessful change initiative creates a legacy of failure and erodes trust. It undermines trust in the organization; more specifically, it weakens trust in the leadership. Thus, change implementation failure may affect the reputation of the leadership and impedes upward mobility. It creates a ripple effect throughout the organization (Atkinson, 2006). According to Atkinson (2006), the failure may become part of the organization's standardized processes and make future change initiatives difficult to successfully implement.

Moran and Brightman (2000) defined change as a process of transforming goals, structure, and capabilities of an organization to keep up with changing environment. Empirical research revealed a positive correlation between leadership behavior and change initiative success; however, successfully implementation is a challenge. Gilley, McMillan, and Gilley (2009) conducted a study to examine behaviors that are correlated with change effectiveness. Gilley et al. (2009) revealed that motivation, communication, coaching, and developing teams are some of the effective approaches leaders should use to successfully implement change.

The dynamic competitive environment in which organizations operate needs dynamic change strategies for the continued viability of the organization (Yi, Li, Hitt, Liu, and Wei (2016). The dynamic competitive environment places pressure on business leaders' to constantly review existing resources and adjust them as needed. Furthermore, the high costs of change initiative failure warrant business leaders to have knowledge, capabilities, and skills to implement change initiatives effectively. Thus, the purpose of this quantitative correlational study was to examine the relationship between idealized behavior and change initiative success.

\section{Literature Review}

Leadership is the ability of an individual to positively influence followers by securing commitment toward attaining organizational goals (Choi, Goh, Adam, \& Tan, 2016). Avolio (1999) defined transformational leadership as behavior exhibited by individuals who transcend their own interests for the benefit of the organization and greater good. However, due to dynamic environment force, leaders have to constantly evolve (Burke \& Noumair, 2015). Leaders using transformational leadership approach motivate followers to be engaged and committed to organizational goals, which results in improved performance (Gaipin, Whittington, \& Bell, 2015). Transformational leadership is associated with behaviors necessary to influence employees to achieve positive outcomes.

Burns (1978) developed the transformational leadership theory and identified four key constructs: (a) idealized influence, (b) inspirational motivation, (c) intellectual stimulation, and (d) individualized consideration. Idealized influence is further subdivided into two components: idealized attributes and idealized behavior. According to Downe, Cowell, and Morgan (2016), idealized behavior is a transformational leadership behavior that positively influences the behavior of subordinates. Downe et al. (2016) argued that leaders who utilized a transformational leadership approach are more likely to have followers emulate their attractive behavior. Subordinates emulate the positive behavior of the leader to achieve common goals.

Idealized behavior is based on the ability of the leader to influence followers to act in respectful ways. Followers are influenced by the behaviors of their leaders (Northouse, 2018). They emulate the values and beliefs of the leaders they idealized. Leaders who exhibit idealized behavior influence their followers; in return, followers emulate the behavior (Quintana, Park, \& Cabrera, 2015). Transformational leaders are visionary, trusted, and respected (Avolio, 1999). Followers identify with transformational leader's vision, which makes it easier to accomplish common goals. An idealized behavior is often identified as the force that motivates followers to be creative (Quintana et al., 2015). Idealized leaders empower employees to be creative and accomplish organizational goals. 
Nging and Yazdanifard (2015) argued that transformational leadership is an effective leadership approach required to successfully implement change initiatives. Chou (2014) studied the effects of transformational leadership behavior on change initiatives. Chou revealed that transformational leadership is an effective leadership style to motivate followers to support change initiatives. Van Wart (2012) posited that there is a positive correlation between transformational leadership and organizational change success.

The most influential research on leadership behavior was conducted by Hemphill (1950) in an early Ohio State University study. Hemphill (1950) developed a leader behavior descriptor questionnaire to measure and understand perceptions of leadership behaviors. The instrument had items rating how leaders should behavior to items rating perception of leadership behavior (Halphin, 1957). Hemphill found that leaders of large groups showed high structure and low consideration. Badin (1974) conducted a study similar to Hemphill, he found that structure was positively related to effectiveness in large groups.

\section{Research Methodology}

A correlational design was the appropriate design to examine how the predictor correlates to the outcome. Participants were midlevel managers employed by large organizations in any industry in the United States and have successfully implemented organizational change initiatives. For the purpose of this research, we defined a large organization as a business with over 500 employees. According to U.S Census Bureau (2017), a large business is a company that employs 500 or more individuals.

A total of 105 mid-level managers participated in the study. Inclusion criteria provide guidelines for selecting participants who match a set of criteria (Rahman, 2015). In this study, inclusion criteria for selection of participants included mid-level managers working for large organizations in any industry in the United States, 18 years or older, and have successfully implemented at least one or more change initiative projects. A convenience sampling technique was used to select participants.

We used a self-administered questionnaire with closed-ended questions to collect data from the participants. Researchers commonly use self-administered surveys as a quantitative method of data collection using closed-ended questions (Díaz de Rada \& Domínguez-Álvarez, 2014). Advantages of using a questionnaire as a data-collection technique include flexibility, relative cheapness, and ease of administration (Bryman, 2016). Song, Son, and Oh (2015) argued that closeended questionnaires are easy to administer and minimize bias. A questionnaire was distributed to participants through SurveyMonkey platform.

Multifactor Leadership Questionnaire (MLQ) 5X-Short, a self-reporter questionnaire was used to measure the independent variable (idealized behavior). Only four MLQ items pertaining to idealized behavior, out of the 20 transformational leadership items, were used to measure the independent variable. Participants rated idealized behavior using a 5-point Likert scale $(0=$ not at all to 4 = frequently, if not always). Project Implementation Profile (PIP) survey instrument was used to measure the dependent variable (change initiative success). The10 items that pertain to project success were used to measure the dependent variable. Participants rated change initiative success using a 7 -point Likert scale ( $1=$ strongly disagree to $7=$ strongly agree $)$.

According to Jeon (2015), researchers use regression analysis to identify the influence of the independent variable on a dependent variable and establish the relationship between an independent variable and a dependent variable. We used simple linear regression to predict the dependent variable (change initiative success) from the independent variable (idealized behavior). Beta weight of idealized behavior was used to assess the increase of dependent variable. A beta weight indicated how much one unit increase in the independent variable resulted in a dependent variable increase.

\section{Results and Analysis}

The assumptions of normality and independence of residuals were evaluated with no significant violations noted. Table 1 depicts descriptive statistics for the study variables. Figure 1 depicts a 
normal P-P plot, indicative of a positive linear relationship between idealized leadership behavior and change initiative success. The scatter plot for the predictor variable and dependent variable, as shown in Figure 2, indicates that the two variables are positively correlated such that as idealized leadership behavior increases, the change initiative success also increases. Figure 3 depicts a histogram, indicative of a normal distribution.

Table 1 Descriptive Statistics for Study Variables

\begin{tabular}{lcc}
\hline Variable & $M$ & $S D$ \\
\hline Idealized Behavior & 2.67 & .74 \\
Change Initiative Success & 5.51 & .87 \\
\hline
\end{tabular}

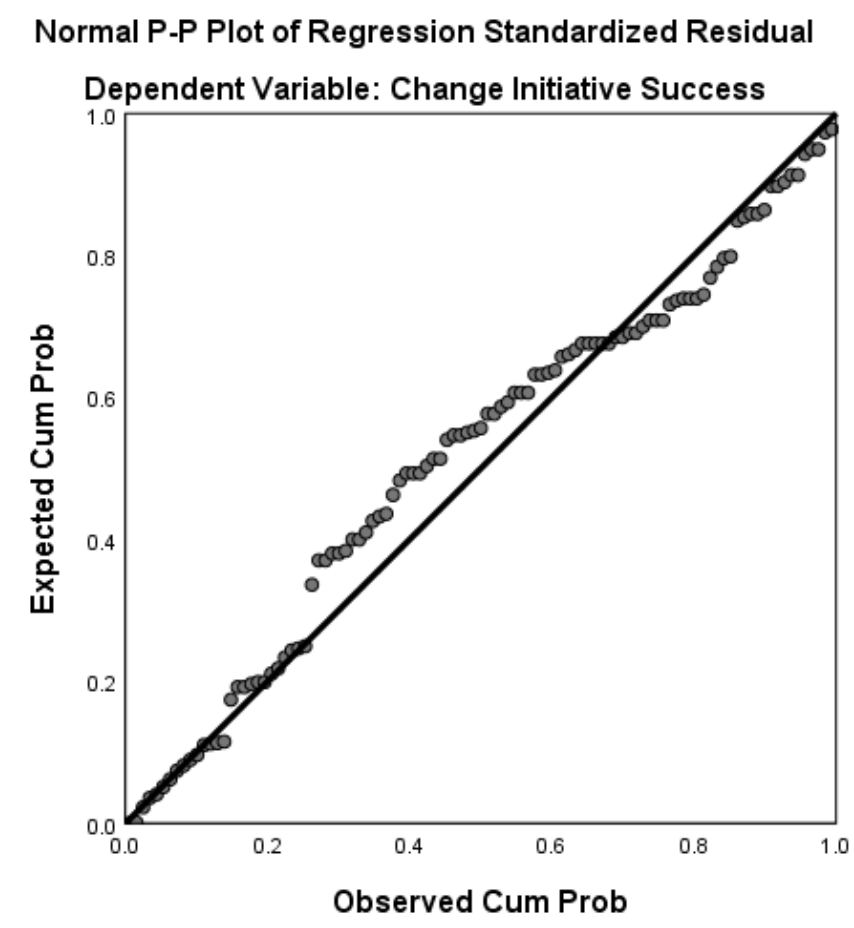

Figure 1. Normal probability plot (P-P) of the regression standardized residuals. 


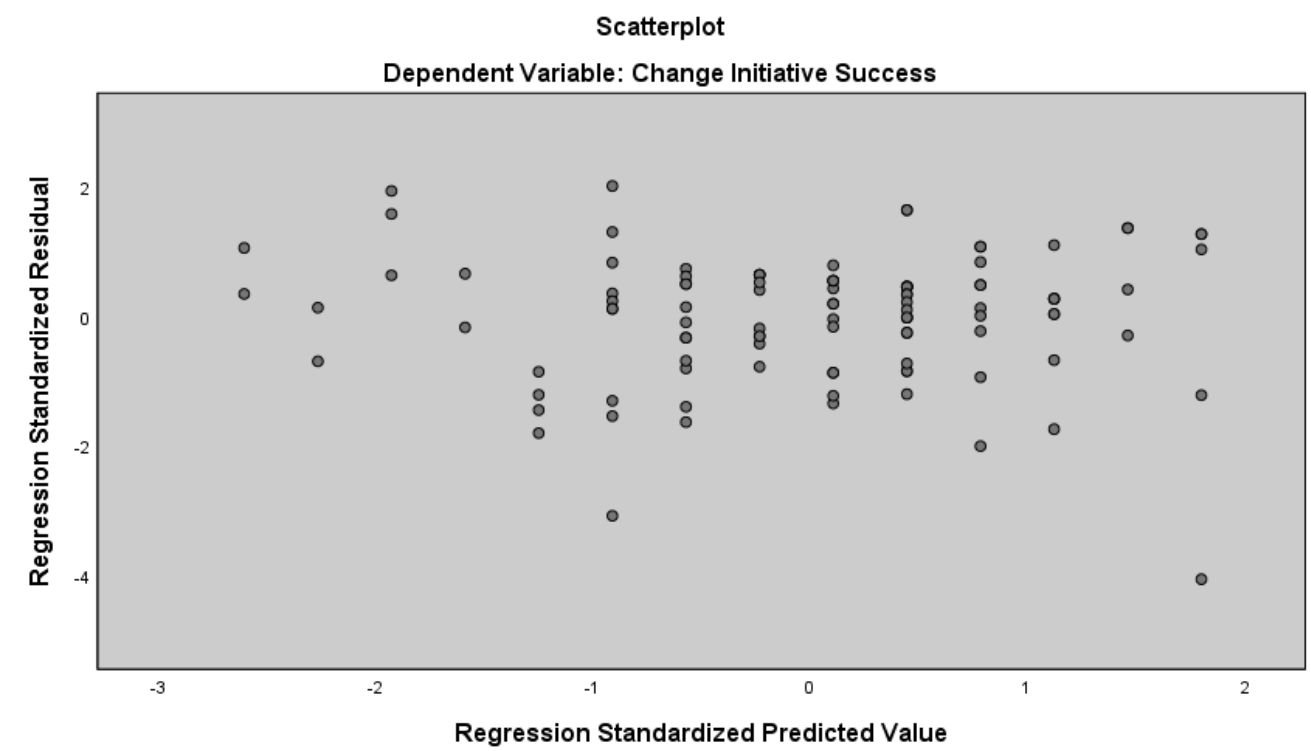

Figure 2. Scatterplot of the standardized residuals.

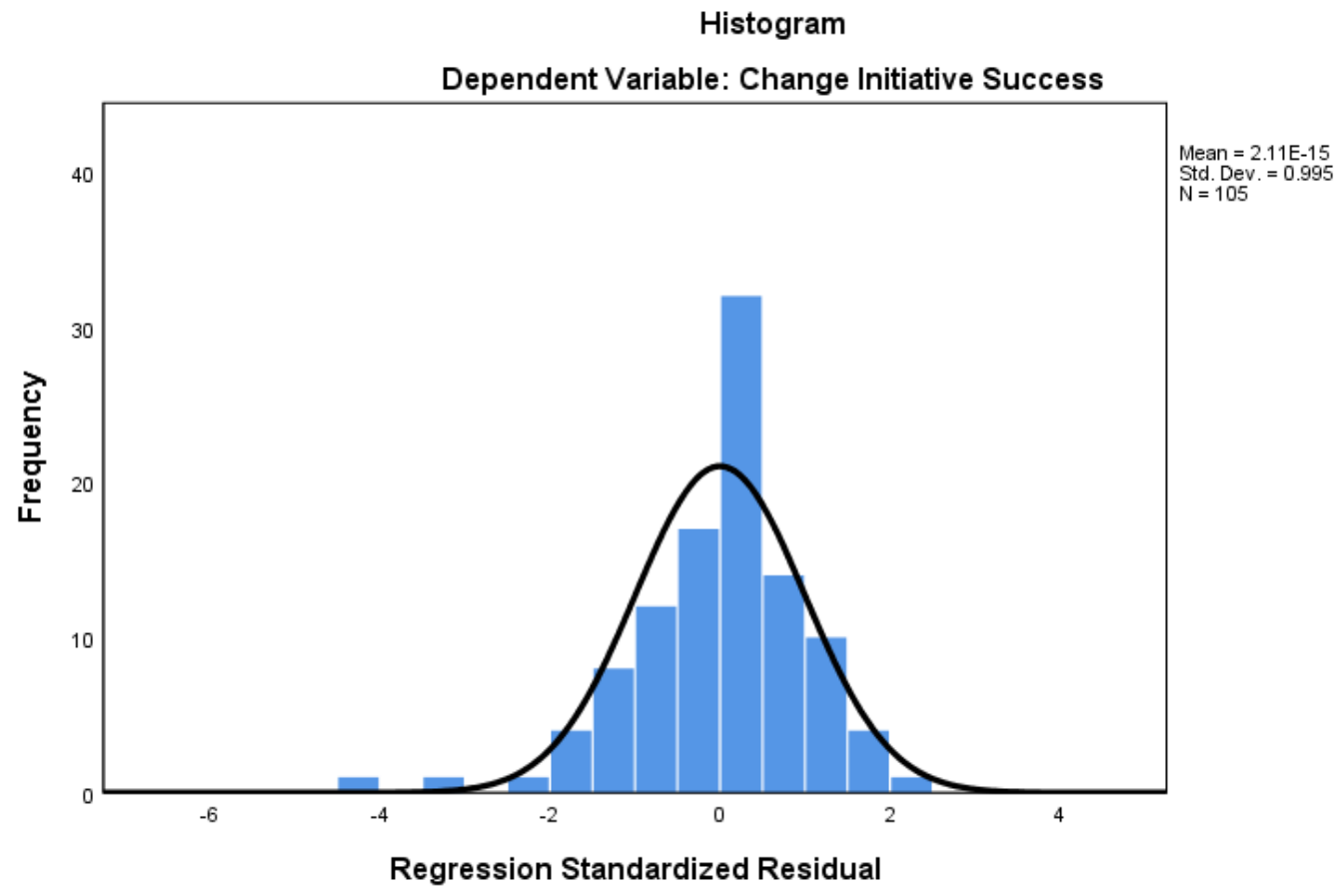

Figure 3. Histogram of change initiative success.

\begin{tabular}{|c|c|c|c|c|}
\hline \multicolumn{5}{|c|}{ Model Summary $^{b}$} \\
\hline Model & $\mathrm{R}$ & R Square & $\begin{array}{c}\text { Adjusted R } \\
\text { Square }\end{array}$ & $\begin{array}{l}\text { Std. Error of } \\
\text { the Estimate }\end{array}$ \\
\hline 1 & $.265^{\mathrm{a}}$ & .070 & .061 & .84505 \\
\hline
\end{tabular}




\begin{tabular}{|c|c|c|c|c|c|c|}
\hline \multicolumn{7}{|c|}{ ANOVA $^{a}$} \\
\hline \multicolumn{2}{|c|}{ Model } & $\begin{array}{l}\text { Sum of } \\
\text { Squares }\end{array}$ & $\mathrm{df}$ & Mean Square & $\mathrm{F}$ & Sig. \\
\hline \multirow[t]{3}{*}{1} & Regression & 5.572 & 1 & 5.572 & 7.803 & $.006^{\mathrm{b}}$ \\
\hline & Residual & 73.554 & 103 & .714 & & \\
\hline & Total & 79.126 & 104 & & & \\
\hline
\end{tabular}

a. Dependent Variable: Change Initiative Success

b. Predictors: (Constant), Idealized Behavior

\begin{tabular}{|c|c|c|c|c|c|c|c|}
\hline \multirow[b]{3}{*}{ Model } & \multicolumn{4}{|c|}{ Coefficients $^{\mathrm{a}}$} & & & \\
\hline & \multicolumn{2}{|c|}{$\begin{array}{l}\text { Unstandardized } \\
\text { Coefficients }\end{array}$} & \multirow{2}{*}{$\begin{array}{c}\text { Standard } \\
\text { ized } \\
\text { Coefficie } \\
\text { nts } \\
\text { Beta } \\
\end{array}$} & \multirow[b]{2}{*}{$\mathrm{t}$} & \multirow[b]{2}{*}{ Sig. } & \multicolumn{2}{|c|}{$\begin{array}{c}95.0 \% \text { Confidence } \\
\text { Interval for B }\end{array}$} \\
\hline & $\mathrm{B}$ & $\begin{array}{l}\text { Std. } \\
\text { Error }\end{array}$ & & & & $\begin{array}{l}\text { Lower } \\
\text { Bound }\end{array}$ & $\begin{array}{l}\text { Upper } \\
\text { Bound }\end{array}$ \\
\hline (Constant) & 4.674 & .311 & & $\begin{array}{r}15.02 \\
7\end{array}$ & .000 & 4.057 & 5.291 \\
\hline $\begin{array}{l}\text { Idealized } \\
\text { Behavior }\end{array}$ & .314 & .112 & .265 & 2.793 & .006 & .091 & .536 \\
\hline
\end{tabular}

a. Dependent Variable: Change Initiative Success

Figure 4. The results of the simple linear regression analysis.

A simple linear regression analysis was conducted to evaluate the prediction of the change initiative success index from the idealized behavior index for large organizations in the United States. The independent variable was idealized behavior. The dependent variable was change initiative success. The null hypothesis was that there is no statistically significant relationship between idealized behavior and change initiative success. The alternative hypothesis was that there is a statistically significant relationship between idealized behavior and change initiative success. The regression equation for predicting the change initiative success index is

Change Initiative Success $=4.674+.314$ Idealized Behavior

The $95 \%$ confidence interval for the slope is fairly wide (.091 to .536) and positive throughout the range of the interval. The $95 \%$ confidence interval does not contain zero; therefore, the idealized behavior is positively correlated to change initiative success. As hypothesized, there is a statistically significant relationship between idealized behavior and change initiative success. The correlation between the idealized behavior and change initiative success was .265. The model was able to significantly predict change initiative success: $F(1,103)=7.803, p<0.006, R^{2}=0.070$. The $R^{2}$ (0.070) value indicates that approximately $7 \%$ of the variance of change initiative success is accounted for by its linear relationship with the idealized behavior index. The positive value for idealized behavior as a predictor indicated a 0.314 increase in change initiative success for each additional unit in idealized behavior. In other words, change initiative success tends to increase by one unit as idealized behavior increases.

Ineffective leadership is one of the leading causes of organizational change implementation failure. Empirical research studies revealed that the use of transformational leadership approach leads to change initiative success. The results of this study are significant to business leaders as they might gain understanding of relationship between idealized behavior and change initiative success. In 
addition, leaders might gain a practical approach in reducing the change initiative implementation failure, which could minimize the high costs of failure. The practical approach could also lead to business leaders gaining knowledge necessary to effectively implement change initiative projects.

Based on the results of this study, we recommend that business leaders should have metrics to measure the implementation success of change projects. Yi et al. (2016) suggested that organization should have metrics to measure change initiative success. Bass and Avolio (1990) also suggested that all leaders in an organization should use a transformational leadership style. Therefore, we recommend that business leaders should use transformational leadership approach to affect the implementation of change positively. In addition, Bass and Avolio recommended organizations should use MLQ questionnaire in leadership training to determine the leaders' strengths and weaknesses and improve decision making, especially during organizational change initiatives.

\section{Research Limitation and Future Direction}

The first limitation of the study is that data collected from participants lacked detailed responses because the survey questionnaire used to collect the data consisted of closed-ended questions. The second limitation is the use of a nonprobability convenience sampling technique. Convenience sample might have limited the results to the population sample. According to Landers and Behrend (2015), the use of convenience sampling technique limits the potential generalizability of results to the population sample. Recommendations for future research include the use of probability sampling techniques such as random sampling to potential generalize the results. A probability sample is more representative of the study population. Future studies could also use mixed-methods research methodology to further address the complexity of organizational change initiatives.

\section{Conclusion}

In this study, we examined the relationship between idealized behavior and change initiative success. The results revealed a statistically significant positive relationship between idealized behavior and change initiative success. The independent variable (change initiative success) was also significant. The results were consistent with the existing literature on idealized behavior and change initiatives. Empirical studies have consistently revealed a positive correlation between transformational leadership and change initiative success. The results of the study provide a practical model for understanding the relationship between idealized behavior and change initiative success.

\section{References}

Al-Haddad, S., \& Kotnour, T. (2015). Integrating the organizational change literature: A model for successful change. Journal of Organizational Change Management, 28, 234-262. doi:10.1108/JOCM-11-2013-0215

Atkinson, A.A., Waterhouse, J.H., \& Wells, R.B. (1997). A stakeholder approach to strategic performance measurement. Sloan Management Review, 38, 25-37. Retrieved from https://sloanreview.mit.edu/

Avolio, B. J. (1999). Full leadership development: Building the vital forces in organizations. Thousand Oaks, CA: Sage.

Bass, B. M., \& Avolio, B. J. (1990). Transformational leadership development: Manual for the multifactor leadership questionnaire. Palo Alto, CA: Consulting Psychologists Press.

Bryman, A. (2016). Social research methods. Oxford, United Kingdom: Oxford University Press.

Burke, W. W., \& Noumair, D. A. (2015). Organization development: A process of learning and changing. Upper Saddle River, NJ: Pearson Education.

Burns, J. M. (1978). Leadership. New York, NY: Harper \& Row.

Choi, S. B., Kim, K., \& Kang, S. W. (2017). Effects of transformational leadership and shared leadership styles on employees' perception of team effectiveness. Social Behavior and Personality: An International Journal, 45, 377-386. doi:10.2224.sbp.5805

Chou, P. (2014). Does transformational leadership matter during organizational change? European Journal of Sustainable Development, 3, 49-62. doi:10.14207/ejsd.2014.v3p49 
Choy, L. T. (2014). The strengths and weaknesses of research methodology: Comparison and complimentary between qualitative and quantitative approaches. Journal of Humanities and Social Science, 19, 99-104. Retrieved from https://www.iosrjournals.org

Cooke, M. (2017). Is technology change threatening the very existence of traditional survey research and, if so, what should we do about it? International Journal of Market Research, 59, 153155. Retrieved from http://journals.sagepub.com/home/mre

Diaz de Rada, V., \& Dominguez-Alvarez, J. A. (2014). Response quality of self-administered questionnaires: A comparison between paper and web questionnaires. Social Science Computer Review, 32, 256-269. doi:10.1177/0894439313508516

Downe, J., Cowell, R., \& Morgan, K. (2016). What determines ethical behavior in public organizations: Is it rules or leadership? Public Administration Review, 76, 898-909. doi:10.1111/puar.12562

Gaipin, T., Whittington, J. L., \& Bell, G. (2015). Is your sustainability strategy sustainable? Creating a culture of sustainability. Corporate Governance, 15, 1-17. doi:10.1108/CG-01-2013-0004

Gilley, A., McMillan, H. S., \& Gilley, J. W. (2009). Organizational change and characteristics of leadership effectiveness. Journal of Leadership \& Organizational Studies, 16(1), 38-47. doi: $10.1177 / 1548051809334191$

Halphin, A. W. (1957). Manual for the leader behavior description questionnaire. Columbus, OH: Ohio State University.

Heckmann, N., Steger, T., \& Dowling, M. (2016). Organizational capacity for change, change experience, and change project performance. Journal of Business Research, 69, 777-784. doi:10.1016/j.jbusres.2015.07.012

Hemphill, J. K. (1950). Relations between the size of the group and the behavior of superior leaders. The Journal of Social Psychology, 31, 11-22. doi: 10.1080/00224545.1950.9919026

Jeon, J. (2015). The strengths and limitations of the statistical modeling of complex social phenomenon: Focusing on SEM, path analysis, or multiple regression models. International Journal of Social, Behavioral, Economic, Business, and Industrial Engineering, 9, 16341642.

Landers, R. N., \& Behrend, T. S. (2015). An inconvenient truth: Arbitrary distinctions between organizational, Mechanical Turk, and other convenience samples. Industrial and Organizational Psychology, 8, 142-164. doi:10.1017/iop.2015.13

Moran, J. W., \& Brightman, B. K. (2000). Leading organizational change. Journal of Workplace Learning, 12, 66-74. doi:10.1108/13665620010316226

Nging, T. K., \& Yazdanifard, R. (2015). The general review of how different leadership styles cause the transformational change efforts to be successful. International Journal of Management, Accounting, and Economics, 2, 1130-1140. Retrieved from http://www.ijmae.com/

Northouse, P. G. (2018). Leadership: Theory and practice (8th ed.). Thousand Oaks, CA: Sage.

Quintana, T., Park, S., \& Cabrera, Y. (2015). Assessing the effects of leadership styles on employees' outcomes in international luxury hotels. Journal of Business Ethics, 129, 469-489. Retrieved from https://www.jstor.org/

Rahman, S. (2015). Ethical issues of fair subject selection in the research. Bangladesh Journal of Bioethics, 6, 37- 40. doi:10.3329/bioethics.v6i3.27619

Saunders, M., Lewis, P., \& Thornhill, A. (2016). Research methods for business students (7th ed.). Upper Saddle River, NJ: Pearson Education.

Song, Y., Son, Y. J., \& Oh, D. (2015). Methodological issues in questionnaire design. Journal of Korean Academy of Nursing, 45, 323-328. doi:10.4040/jkan.2015.45.3.323

U.S. Census Bureau (2017). North American Industry Classification System (NAICS). Retrieved from https://www.census.gov/eos/www/naics/

Van Wart, M. (2013). Lessons from leadership theory and the contemporary challenges of leaders. Public Administration Review, 73, 553-565. doi:10.1111/puar.12069

Yi, Y., Li, Y., Hitt., M.A., Liu, Y., \& Wei, Z. (2016). The influence of resource bundling on the speed of strategic change: Moderating effects of relational capital. Asia Pacific Journal of Management, 33, 435-467. doi:10.1007/s10490-016-9458-z 